\title{
The faith closet
}

\section{Caroline Humphrey ${ }^{1}$}

Summary: This article is based upon research with student social workers and their educators which foregrounded the personal-professional interface in becoming a social worker. Faith was an explicit dimension of this research project insofar as an interest in spirituality and religion is returning to social work and insofar as the author has embarked upon her own inter-faith journey. It was also rather elusive insofar as faith-based students often construct a closet in which to conceal their faith in a predominantly secular world. The workings of the closet and the workings of faith are explored in relation to professional education, ethics and practice as well as research into these territories.

Keywords: faith closet; social work

1. Senior Lecturer in Social Work

Address for Correspondence: Department of Social Sciences, University of Hull, UK HU6 7RX. c.humphrey@hull.ac.uk

Acknowledgement:The author would like to thank the students and educators who participated in this project and to acknowledge the HEFCE funding which supported its completion.

Date of publication: 26th October 2009

7 Journal of Practice Teaching \& Learning 8(3) 2008, 7-27. DOI: 10.1921/146066909X478271. @ w\&bb 


\section{Introduction}

The origins of social work in Western societies can be traced to Christian philanthropy (Woodroofe, 1961). Its education and practice was subject to a progressive secularisation in the twentieth century as the profession reflected the secular modernity of communities, governments and social sciences. During the past decade there has been 'a return of the repressed', borrowing from psychodynamic terminology, with a resurgence of interest in religion and spirituality in social work. Initially, this interest appeared to be rather esoteric as it was articulated primarily with reference to 'other cultures' i.e. making sense of minority ethnic communities in the UK whose lifestyles were shaped by religion (e.g. Crompton, 1998) and social work in the developing world of Africa and Asia where spirituality is inseparable from social work (e.g. Payne, 2005). But there has been a significant shift in law and policy in Britain which heralds an institutionalisation of faith matters. Practitioners are now required to take account of religious aspects of identity and community, and to assess the spiritual needs of service-users and carers (Moss, 2005). Indeed, the spiritual dimension of social care may be deemed co-terminous with the spiritual dimension of our humanity, in which case all social workers need to become spiritually sensitive practitioners (Canda and Furman, 1999).

The question is whether social work is ready for such a challenge? The problem is at least twofold. On the one hand, the majority of social workers will reflect the belief-systems of the mainstream secular society around them since beliefs cannot be sustained in a vacuum and all beliefs depend upon the plausibility structure of social institutions to endow them with truth and meaning (Berger, 1969). An atheist could not survive in a community based upon voodooism or Hinduism, and a Hindu would struggle to survive in a society dominated by Christianity or atheism. On the other hand, social work values have been articulated with reference to the politics of anti-oppressive practice rather than the morals or metaphysics associated with religions (Dominelli, 1997). Religion and spirituality may therefore be regarded as superfluous to the movement for social justice, or even detrimental to it, although there are now humanist, feminist, eco-friendly and socially engaged forms of religion and spirituality which do work for social justice (Consedine, 2002; King, 2008).

8 Journal of Practice Teaching \& Learning 8(3) 2008, .7-27. DOI: 10.1921/146066909X478271. @ wE-b 
During the period 2004-08 I have been engaged in a longitudinal research project into the education of social work students in England which may shed light on faith matters. It was an ethnographic study insofar as my own subject-position was simultaneously that of a researcher and educator in relation to students, and that of a researcher and colleague in relation to staff. As such it harbours the virtues of maximising insider understandings at the grassroots, but also raises predicaments around clarifying role-boundaries in situ and maintaining confidentiality vis-à-vis sensitive stories (Coghlan and Brannick, 2005).

This article is structured into four sections which are bound together by the closet metaphor. The first section gives an overview of the project in order to illustrate the ways in which beliefs were addressed and to introduce readers to the notion of a faith closet, and the second section explores the workings of this closet during research interviews in more detail. In the third section professional values will be considered in relation to personal beliefs, and in the fourth section the workings of faith and non-faith are considered in relation to professional practice. The conclusion invites educators and students to enter into a dialogue on faith matters, and provides a typology of positions to illustrate the conditions under which such dialogue can be facilitated or frustrated.

\section{Questioning methods in relation to beliefs}

Questions of faith have been an explicit albeit elusive dimension of my research into social work education where I have traced the trajectories of students on a BA in Social Work programme with reference to the personal-professional interface. A survey was administered to a whole cohort of 80 students in their first week on the programme and this included a question as to whether or not they had any kind of 'faith, religion or spirituality'. Of the students, 43 (54\%) responded in the negative; 29 (36\%) in the affirmative, and they included all of the overseas students and many of the mature students over the age of 30 years; and 8 (10\%) selected the 'unsure' option.

Over the next three years a variety of other methods came into play. One-to-one interviews were conducted with 30 volunteers at different stages of the programme and 14 students offered significant material around faith matters. Six focus groups were convened during practice

9 Journal of Practice Teaching \& Learning 8(3) 2008, 7-27. DOI: 10.1921/146066909X478271. @ wE-b 
placements and significant dialogues around religion and spirituality emerged in three groups containing a total of 14 students who came from a variety of faith-based and non-faith traditions. 40 portfolios have been read for research purposes but only a quarter of them contained references to religion and spirituality. 25 educators have also participated in individual, dyadic and group interviews, although the project did not involve working with student-supervisor pairs.

It was the elusive nature of faith in terms of its virtual absences and presences, or its alternating appearance-and-disappearance, which led me to the notion of a faith closet. After a series of individual interviews with students where the faith question had drawn a blank, I decided to abandon the question on the assumption that if faith was significant for a student we would have a student-instigated discussion on the matter. During the next interview I was convinced that the student was grounded on and guided by faith, particularly when she offered examples of critical and creative practice where she challenged the status quo regardless of the potential consequences to herself, as her entire dialogue seemed to be informed by an ethos of transcendence. But there was not a single concrete reference to anything resembling faith and therefore no opportunity to catch hold of a comment and convert it into a question. After my specified time-limit of interviews (90 minutes) I brought the conversation to a close and succumbed to the temptation to raise the faith question myself:

CH: I think we're going to have to bring it to a close there.

S: Close now, yes.

$\mathrm{CH}$ : You've been fascinating, but there's only one thing I would like to ask you and it might be very quick. I'm just wondering what keeps you going at the lovely, bubbly level that you are? I'm just wondering whether you had any spiritual tradition behind you?

S: Yes, I do, yes, definitely... I was brought up in a Catholic family but I would say that it's Charismatic [now] and I run the Prayer Group. It's faith, it's definitely my faith that keeps me going .... I lost my eye ... [People say] 'Why weren't you born perfect?' and so on, but I hope that my faith takes me beyond that... People say 'What are we made up of as human beings?' Well, to me spirituality comes first, then emotionally and then physically... My faith is my grounding, definitely.

And so we embarked upon a second mini-interview on faith matters. But why had a student who regarded faith as the grounding of her

10 Journal of Practice Teaching \& Learning 8(3) 2008, .7-27. DOI: 10.1921/146066909X478271. @ wE-b 
being-human and becoming-a-social-worker chosen not to mention this? In this case the student was out and proud about her faith in all settings other than social work education and practice, and she had constructed a closet around her faith specifically as a result of her experiences on the social work programme which had taught her that academics adopted an agnostic-atheist standpoint and that practitioners were unable to contemplate spiritual-religious matters even over the Christmas holidays (holy days) in a residential establishment when they served meals and gave gifts to residents. The result was that I reverted to asking the faith question explicitly in subsequent interviews with students.

Questioning educators about the potential relevance of religion and spirituality was also problematic. Many interviewees had either not discussed such matters with students, or had not deemed them to be relevant to social work. Others offered negative case scenarios suggesting that a student's religion was incompatible with social work; for example, one student's belief that everything was in accordance with God's will had interfered with his capacity to make essential interventions in the lives of families. The result was that dialogues on such matters tended to be foreclosed or foreshortened. Nevertheless, an episode towards the end of these interviews indicated that there may be merit in persisting with such questioning, since material around religious and spiritual matters may be subject to erasure in a secular society, and the traces which remain may require more time and thought for their reawakening. This practice teacher specialised in the field of mental health, and we had long discussions about values during which she insisted that cultural matters pertaining to religion and spirituality were irrelevant, although I made comments to the effect that they were important to some students. Towards the end of the interview these matters cropped up again and her entire persona underwent a dramatic transformation as she came out with a number of exclamations such as 'Wow!' and 'My head is spinning!' preceded and followed by long silences. Eventually she told me that she had remembered something significant in connection with spirituality and mental health. She had undertaken some workshops at a Buddhist Centre as part of her approved social worker training in mental health matters. The working monks would take clients in crisis as an alternative to hospitalisation and specialised in dealing with people suffering psychotic episodes. They would enable these people to reconnect with

11 Journal of Practice Teaching \& Learning 8(3) 2008, 7-27. DOI: 10.1921/146066909X478271. @ wE-b 
themselves and their environment by walking alongside them, listening to them in a non-judgemental manner and asking them what they were experiencing through their sensory faculties. As far as this practitioner was concerned, this was 'a very social-work-y way of working' and subsequent referrals to them had successful outcomes. Practices from diverse spiritual traditions are indeed proving to be valuable resources in health care settings (e.g. Ng and Chan, 2005; Ridge et al, 2008) and mental health settings (Miller, 1999; Coyte et al, 2007).

Research into religion and spirituality is relatively embryonic in social work and social sciences, and we need to tread carefully in such a sensitive territory where people's sense of selfhood and conception of the world, even their 'spirit' and 'culture', can become a topic for questioning. The empirical researcher is not exempt from such dynamics; the child psychiatrist Robert Coles (1990) reports that children regularly enquired about his own beliefs, which often left him floundering for answers to unanswerable questions about life, death, Creator and cosmos. This occurred during one of my own focus groups, so that I had to make a split-second decision about whether to come out of my own closet:

S: What religion are you, if you follow a religion?

CH: I have been influenced by a number of religions and I also had a long period of being an atheist ... because I was so disillusioned [with religion] ... I went by chance to a Summer Solstice Festival which turned out to be a pagan festival - it is very women-centred, whereas a lot of religions are very man-centred. Then I took up yoga, again by chance at a Buddhist Centre. I was there a long time, studying and meditating and chanting... Since I moved up here I haven't found anything like that, but I currently visit a Catholic church where I meditate in the corner, and where the local priest is absolutely great. So I have a lot of influences.

This 'turning the tables' can counteract the power-knowledge asymmetry between researchers and participants, and although as a general rule researchers would not volunteer information about their own backgrounds of their own accord, the willingness to open ourselves up on a sensitive subject militates against the potential hypocrisy in hiding in our own closets whilst inviting others to come out of theirs. In relatively closed communities where participants interact with one another, any self-disclosures from the researcher will be magnified, and by the final year of the project my question on faith did not come as a surprise to those who volunteered for interviews on account of the

2 Journal of Practice Teaching \& Learning 8(3) 2008, .7-27. DOI: 10.1921/146066909X478271. @ wEbb 
workings of the student grapevine. This may have encouraged students with faith to come foreward, but it did not appear to deter students with no-faith from doing so.

\section{The workings of the closet}

A closet in the literal sense is a small back-room in which people can have private conversations or a secret cupboard known only to the householder. It has become a popular metaphor in everyday life when referring to 'skeletons in the closet', and it has been appropriated by lesbians and gay men who agonise about 'coming out of the closet' in case this adversely affects their life-chances in a largely heterosexual world, a dynamic which also affects lesbian and gay social workers (see Humphrey, 1999). There is merit in applying this metaphor to faith in a secular society since there can be stigma attached to religion and spirituality in a modernity governed by the norms and values of rationalinstrumental-scientific reasoning (Giddens, 1990). This stigma has been compounded by the ways in which some religious leaders and their followers have pursued or perverted their faith (see Kennison, 2008). Closets are constructed to safeguard something which is significant to the self under conditions where it may be unsafe to share it with others, and they can hide treasure-troves and rotting corpses alike.

The closet metaphor was helpful during the conduct of interviews with students as it enabled me to be sensitive to dynamics and defences operating at the personal-professional interface, and I formulated an injunction to myself to 'knock on the door and wait' whenever I suspected the presence of a closet around faith matters. By the end of the research project I realised that this closet could be constructed in a complex, contradictory and contingent manner. In other words, students with no faith could also have a closet in which they concealed spiritual or religious skeletons; there were also closets within closets; there can be an entire spectrum from consciousness to non-consciousness in relation to our own closets; and choices about whether to stay in or come out of the closet could change rapidly.

Even the conditions under which students had 'no closet' in relation to faith matters proved to be diverse. One student was 'out and proud' about her multi-faceted spirituality which she had cultivated throughout

13 Journal of Practice Teaching \& Learning 8(3) 2008, 7-27. DOI: 10.1921/146066909X478271. @ wE-b 
her adult life in a highly self-conscious manner. Another student was the daughter of a religious minister who regarded her career in social work as an extension of her religious faith and who prayed for her clients during family gatherings. In this case a specific religion had been naturalised in an almost subconscious manner, and it would have been inconceivable for this student to conceal her faith in a closet. Two students had recently discovered their own spirituality at the point of the research interview, one as a result of walking through a Zen garden during a vacation, and the other at a result of a practice placement in a hospice setting. These students shared their recent discoveries with me as soon as I asked the faith question in a carefree and unselfconscious manner, and one of my hypotheses is that embryonic spirituality which has not yet given itself a name may not need a closet in which to hide.

The most obvious faith closets were those constructed by overseas students from Christian communities on the African continent. They have good reason to construct closets-within-closets when they embark upon social work training in a predominantly white secular region of Britain, and they tend to seek refuge in church-based communities. Most overseas students responded to my faith question by explaining that they maintained a separation between personal and professional matters, and that their faith came into the former category, a divide which I respected.

The closets maintained by home students (both white British students and those from minority ethnic communities) had far more permeable boundaries. It was as if the closet door had been left ajar so that a discerning eye could glimpse what lurked within and a discerning ear could catch the whisperings of faith. But what does one say to a whispering ghost? How does one confess one's vision of the other's closet to the other who may repudiate it - either because they are unaware of it or because they do not want someone else to become aware of it? This situation became acute in respect of two mature men who repeatedly invoked potentially spiritual concepts (e.g. 'a higher power') and potentially spiritual practices (e.g. meditation) whilst resisting any explicit dialogue around spirituality by switching the conversation to something else (and as soon as this tactic was successful the potentially spiritual concepts and practices would re-surface). By the end of these research interviews an explicit dialogue around spirituality had taken place, and it became clear that these students were seeking to negotiate boundaries with themselves as well as with me during the interview

14 Journal of Practice Teaching \& Learning 8(3) 2008, .7-27. DOI: 10.1921/146066909X478271. @ w\&b 
itself. Both of these men had a conscious commitment to their respective faith-based pathways in life, and both of them made use of faith-based practices in their work, but neither of them had discussed faith matters in education or employment contexts, and they had been taken by surprise by my discerning questioning. In other words, they had to make the decision on whether to open up or lock up the closet door during the interview itself.

There were also students who harboured some kind of faith at a sub-conscious level and for whom the research interview constituted a turning-point in their self-consciousness. On one occasion this was a traumatic turning-point in so far as a student who regularly referenced her belief in 'fate' responded with horror to my question about whether this had any relationship to 'faith'? It emerged that she had substituted her belief in fate for her prior belief in God after she had made a decision to do something (with good reason) which she thought was likely to be abhorrent in the eyes of God. My question had woken up other skeletons in her closet, although the student returned to see me some time later to explain that her confession and my compassion had contributed to her healing.

Dynamics around closets were also evident in the focus groups. In the first group an overseas student twice denied having any faith and waited until all the other students discussed their diverse faith-based and non-faith-based standpoints before coming out as a fundamentalist Christian. In the second group a pagan rapidly constructed a closet in which to safeguard his faith in a setting where he was in a minority of one in the midst of agnostic and atheist students, although he had previously been 'out and proud' about his paganism with its feminist and eco-political credentials. In essence, he confessed his faith; his peers told him in no uncertain terms that it was not relevant to his profession; I challenged this message but the other students responded by telling the pagan that they 'didn't care what he was as long as he didn't force it on them'; after which he insisted that his faith had no relevance to anything or anyone at all. In the third group all the students subscribed to some form of spirituality and were delighted to discuss it. But one student who had experienced paranormal phenomena including visitations from an ancestor continued to express concerns about whether members of the group would regard her as 'crazy', in spite of our protestations to the contrary. The ending of this group bears testimony to all of these elements:

15 Journal of Practice Teaching \& Learning 8(3) 2008, 7-27. DOI: 10.1921/146066909X478271. @ wE-b 
S1: It's been refreshing to talk like that in an open manner without thinking 'Oh God, what will they think about me?' ... That's unfortunately the way things are going at the moment S2: -- that you can't talk about these things.

S1: People have to watch their ps and qs, for whatever reason.

$\mathrm{CH}$ : Is there anything else that you want to raise in the last few minutes?

S3: That I'm not a fruit cake. Yeah, I would like to get that on record. I'm not clinically insane, really.

A sense of 'strangeness' and even 'madness' can haunt those who find themselves in a cognitive minority, although the majority or minority status of our perceptions and beliefs may have no bearing upon their truth-value (Berger, 1969). The art of differential diagnosis in relation to religious experiences and mental illness, along with a critique of the conflation of these phenomena by lay publics and psychiatrists alike, is discussed by Edward Canda and Leola Furman (1999).

Of course educators and practitioners can also construct their own closets, and I made no attempt to knock on the door of these closets since I was interviewing them about the personal-professional interface in student learning, and had no remit to explore beyond this. It is interesting that a few practice teachers wore a Christian cross around their necks, but did not provide any examples of the relevance or otherwise of faith in practice teaching and learning. Recent research suggests that faith constitutes something of a taboo topic in practice teaching circles (Gilligan, 2003), although surveys suggest that a significant minority of practitioners in the UK do identify with a religion or spirituality (mostly Christian) and would be keen to incorporate faith matters into the curriculum and practicum (Furman et al, 2004).

\section{Questioning values in relation to beliefs}

Interviews with students demonstrated that they regarded their personal beliefs as the foundation of their professional values, endowing these professional values with greater authenticity, and this was true regardless of whether their belief-systems revolved around secular, scientific, religious or spiritual world-views (see Humphrey,

16 Journal of Practice Teaching \& Learning 8(3) 2008, .7-27. DOI: 10.1921/146066909X478271. @ w\&b 
2008). Interestingly, the notion of 'vocation' itself can be traced back to religious roots in Judaism (Eastham, 2002). But interviews with educators indicated that many regarded the relationship between personal beliefs and professional values as problematic, particularly in relation to students with religious backgrounds. World religions have been associated with belief-systems which have subordinated women, legitimated caste systems and persecuted lesbian and gay people, and their compatibility with anti-oppressive practice is open to question. A number of students in my study identified with 'spirituality' rather than 'religion' since the traditions of indigenous peoples, pagans and Buddhists as well as modern humanist movements are not burdened with such a legacy (see Molloy, 2008).

Social work values are characterised by a vagueness which has caused consternation to philosophers (Clarke, 2000), but it is precisely this vagueness which enables them to be appropriated by students and practitioners from diverse backgrounds, since these values can be assimilated into a wide range of pre-existing cognitive schema. The official Code of Practice states that social workers must respect service-users in their individuality and diversity and that they should be safeguarding people from harm, enabling people to make choices and advocating for those who have lost their voice (GSCC, 2002). Social work students sign up to these principles with great ease, and conversations on values are characterised by a consensus bordering on common-sense. But values are more superficial phenomena which can cover-up the diversity of beliefs; beliefs are the cornerstones of the deeper structures of our psyches and cultures and dialogues around beliefs can be characterised by dissent and dogma.

On the basis of conversations with students, I formulated the hypothesis that professional values can be compatible with a wide range of personal beliefs and cultural world-views, but that the content of the underlying beliefs matters less than the manner in which they are nurtured within the self and conveyed to others. A vivid example of this emerged in a focus group in which an atheist and a Christian were at loggerheads. Although these students had previously entered into amicable conversations on professional values, when their underlying belief-systems came to the foreground they entered into battle, making dogmatic claims for their own standpoints and accusing their opponent of being deluded in a manner which cast serious doubts upon their capacity to respect diversity. This group contained students from diverse

Journal of Practice Teaching \& Learning 8(3) 2008, 7-27. DOI: 10.1921/146066909X478271. @ wEb 
backgrounds and the others were working towards a reconciliation of world-views, as testified by the following adherent of Jainism:

S: We've all like come to this little world of social work ... Religion is there for me, beyond all that.... [Turns to a Christian] When you get upset you say 'Jesus'; with me I start saying my prayer to the omniscience ... [Turns to a Buddhist] Like you said about the aspects of Buddhism, it just reminded me that in Jainism we have 'appreciation' like your 'compassion' ... It's a bit like Hinduism too .... There is karma -- the way you live... [Turns again to a Christian] You have that phrase, 'What you reap, so you sow'? ... So it's a bit like Christianity too .... [Turns to an atheist] It's quite scientific as well... The supreme being that we believe in - what I think you'd call a prophet - it's someone who has actually lived and reached nirvana. So there's an actual story to tell, rather than a myth or a legend.

It is noteworthy that this student had been educated in a multi-faith school. Students who had been brought up by dual-faith parents or who had lived in multi-faith neighbourhoods exhibited a deep respect for diversity regardless of their subsequent choices around faith matters in adulthood (cf. Panaser, 2003). It is also noteworthy that such students do have a choice to make around faith matters - arguably they are compelled to make a choice - which makes them different from students who have absorbed a belief-system from their born-to families, regardless of whether their parents were devout Catholics or committed atheists. The ways in which we maintain our world-views within ourselves can have implications for our suitability for social work. Agnostic students have told me that their values are simply based on 'common sense' and Christians have claimed that their values are 'God's values' and that these are identical to 'social work values'. In these cases there is a naturalisation of values and world-views which is arguably dissonant with the social work profession which is steeped in social constructionism (Payne, 2005). My suggestion is that students who recognise the social construction and reconstruction of all worlds-views are likely to become more reflective and more respectful practitioners.

A recurrent quandry in social work education concerns students whose religious beliefs entail a belief in the normality of heterosexuality and the pathology of homosexuality which brings them into conflict with anti-oppressive practice (Canda and Furman, 1999; Bywaters and Jones, 2007). This becomes particularly poignant in situations where

18 Journal of Practice Teaching \& Learning 8(3) 2008, .7-27. DOI: 10.1921/146066909X478271. @ w\&b 
the practice teacher is lesbian or gay, since the student's self-disclosure vis-à-vis religious belief both provokes and renders problematic the supervisor's self-disclosure vis-à-vis sexual orientation. However, the relationship between religion and standpoints on homosexuality is mediated by interpretation, so that some lesbians and gay men are members of churches whose official creed may be anti-homosexuality and some religious students are affirmative of lesbian and gay colleagues and clients. An interesting cameo here was provided by an overseas student who had been struggling with the problem of homosexuality in relation to her Christian family and community for many years. Her mother believed that homosexuality was unnatural and that God had sent HIV/AIDS to punish gay men, and her beliefs hardened when a son she had adopted became gay and later died of AIDS, so that he literally became an outcaste. The student was deeply distressed about this homophobia and remained in secret contact with her brother. She adjusted her understanding of Christianity in a non-judgemental direction, deciding that only God has the authority to judge our worth as human beings, and that she could only believe in a merciful God akin to the Christ in the New Testament, not in the wrathful God of her family and religious community. Since arriving in England she had learned to accommodate to some aspects of the lesbian and gay rights agenda, such as civil partnerships, but she was still struggling with other aspects, such as lesbian and gay parenting, although she had not discussed these predicaments with staff.

This student was actively engaged in the reconstruction of her world-view in a manner which respected the essential truths of her religion without sacrificing her own capacity for reflection. There are faith-based students who adhere literally to their parents' and ministers' interpretations of scriptures without recognising that these authority figures are engaged in a hermeneutic endeavour of interpretation, which may be replete with socio-political biases of all kinds, and this can undermine their capacity for critical reflection and anti-oppressive practice alike. Nevertheless, it would be unwise to 'throw the baby out with the bath water'. World-religions and their sacred scriptures can be interpreted in a manner which facilitates critical reflection and professional ethics (Robinson, 2008). And they can change from within, as testified by the stories of women across the world who are refusing to sacrifice their feminitity or their feminism on the alter of religious patriarchy (King, 2008).

19 Journal of Practice Teaching \& Learning 8(3) 2008, 7-27. DOI: 10.1921/146066909X478271. @ wEbb 


\section{The workings of faith}

Students with a long-standing spiritual or religious faith were adamant that this was the foundation of their personhood but they were less clear on its implications for practice. This may reflect their status as students in so far as they are required to demonstrate conformity to professional and organisational norms which are independent of faith, but it may also reflect the fact that their faith was hidden away in a closet on account of the secularity of the social work world, and consequently there were few opportunities for students to reflect upon the potential virtues and vices of making use of faith in practice. In this section I shall discuss the workings of faith in practice settings in relation to three overlapping spaces i.e. the inner world of the psyche; the outer world in which students relate to others; and the liminal space which overlaps both worlds. I shall then discuss the failure to work with questions of faith among students of no-faith placed in statutory settings.

Faith was all-pervasive in the inner world of the psyche of faith-based students. Faith-based practices were the cornerstone of strategies for stress management and also mediated reflective practice. Prayer was the most common practice among Christian students and some prayed to God every morning and dedicated their day's work to their Maker. One student explained that during a difficult encounter with a service-user her reflection-in-action included an 'arrow prayer to God' where she would pause and ask 'What now, God? How can I help this person now?', trusting that an answer would be forthcoming, if not now, then later. Prayer could be a means of separating out personal and professional values to prevent conflict or contamination. One student was deeply opposed to abortion but had a teenage client who was pregnant and who made a decision to have a termination; the student did not disclose her personal views to the client, but passed the predicament up to God, asking Him to guide the girl prior to the decision, and to forgive her afterwards. Meditation and creative visualisation were the most common practices among other students; sometimes these were supplemented by chanting, dancing, singing or painting. The rich repertoire of practices which these students had developed for the sake of spiritual growth often had a beneficial impact upon their professional development.

Nevertheless, students were extremely wary, and rightly so, of sharing

20 Journal of Practice Teaching \& Learning 8(3) 2008, .7-27. DOI: 10.1921/146066909X478271. @ w\&b 
their faith with service-users. Their main concern was that a disclosure of their own world-view could be construed as oppressive in so far as it could seem as if they were prescribing an interpretive schema for service-users rather than allowing service-users to discover and develop their own schema. The survey of BASW members by Furman et al. (2004) indicated that many faith-based practitioners do make use of their faith in practice settings, particularly when working with people from their own faith background.

In the liminal space which bridges inner and outer worlds there are footprints of faith which can only be detected by those who are attuned to faith matters. Examples of this emerged from students long-versed in the art of meditation and creative visualisation. They could incorporate such techniques into practice repertoires since these had a generic truthand-use-value independent of the faith or non-faith of participants:

S: I teach visualisation techniques... You know, picture yourself in a meadow or picture yourself in the middle of a wood and the sun is shining and the birds are singing... I try getting people to visualise their own place of peace, a place that is special to them... It works... and it draws on their own spirituality but without identifying it as such.

A pagan developed a three-part Relaxation Booklet for young people who suffered anxiety. Part I was a step-by-step guide to controlling and purifying the breath; for example, children can breathe in a pure cloud of fresh air and breathe out a polluted dark cloud which represents taking in good nutrients and letting go of negative baggage. The breath is deemed the essence of the life-force across spiritual traditions but this was not stated explicitly. Part II was a guide to creative visualisation which was illustrated with a picture of 'a Hobbit party in the woods'. The imagery was distinctly pagan but could only be decoded by those familiar with paganism. Part III offered suggestions for how young people could find comforters which they could carry with them in everyday life which could reconnect them to a safe and quiet place inside of themselves when the outside world became too much for them. Again this is a spiritual message in secular guise, but it has value and validity regardless of our world-view.

In the outer world faith has to confess its name if it is to become an explicit element of professional practice. In this world faith matters if and when service-users say that it does and if and when employers tell

21 Journal of Practice Teaching \& Learning 8(3) 2008, 7-27. DOI: 10.1921/146066909X478271. @ wE-b 
us that it does. The service-users who tell students that faith matters to them tend to be from minority ethnic communities and students of faith and non-faith backgrounds alike were equally committed to finding appropriate facilities for their education, recreation and worship. Nevertheless, student interviews and portfolios indicated that there are difficulties in addressing and responding to faith matters. First, religious leaders are not always committed to providing services for stigmatised members of their communities, so that an Iman from a mosque did not respond to requests to work with young people with criminal records in secure units. Second, local authorities have incorporated spiritual and religious orientation within their paperwork so that social workers now have to ask the faith question in respect of all service-users, but in the absence of training it can become a tick-box exercise performed ritualistically to meet legal-bureaucratic requirements. Third, the potential or actual faith of service-users in indigenous communities can be overlooked.

In one local authority child and family workers are required to tick boxes in relation to a child's ethnicity (with 17 categories), a box in relation to the child's first language (with 14 categories) and a box in relation to the child's religion (with 16 categories), but there is little evidence from student portfolios that such check-lists made a difference to assessments or interventions. One student claimed that religion was irrelevant to the lives of families in impoverished communities, and that when parents were asked for information on religion they responded with a curse

S: It's part of the criteria now, to ask about their religion.

$\mathrm{CH}$ : Yes. What do they tend to say?

S: [laughs] 'I don't effing believe in that. It's a load of S.H.I.T.'

Of course people who are struggling to survive may regard religion as redundant, and the discourse around spirituality as constructed by professionals may be alien to lay publics (McSherry, 2006). But here parents are asked the question about their child's religion/spirituality, and research with children shows that their spirituality may be quite autonomous from that of their parents, so that children with atheist parents may discover spirituality or even religion, whilst children with religious parents may become agnostic or atheist (Hay and Nye, 1998).

In the meantime, community care staff are required to complete

22 Journal of Practice Teaching \& Learning 8(3) 2008, .7-27. DOI: 10.1921/146066909X478271. @ wEb 
a section on 'Needs arising from cultural and ethnic background (to include personal, spiritual, dietary and social needs)'. Students tended to offer simple statements to the effect that there were no such needs, such as 'Mrs X has no spiritual or dietary needs'. On occasions a spiritual-social need was recognised, but the plan of intervention made no reference to addressing this need. For example, an elderly woman who was terminally ill informed the student that she had been a regular church-goer all her life but was now unable to attend church, and that this was vital to her spiritual and social well-being, but this need was overlooked in subsequent written agreements as to service provision. Social workers in the UK appear to be lagging behind their counterparts in other countries and professions on this front (Holloway, 2007), and it may be that such oversights are not uncommon.

The only occasions where the religion or spirituality of white British citizens came to the foreground were when students were from a faith background themselves or when they were placed in settings where faith was part of the institutional fabric. A vivid example of the former concerns a Christian student working with a Christian prisoner; the student successfully invoked the Equality Act 2006 to enable the prisoner to have Midnight Mass at Christmas after the prison authorities had refused earlier requests from the prisoner; the student pointed out that other festivals such as Ramadan were routinely respected for prisoners of minority faiths. The best example of the latter concerns hospices since the hospice movement has been attuned to spiritual and religious matters since its inception (see Rees, 2001). However, agnostic or atheist students can experience some discomfort in these settings, particularly when the agency ethos is steeped in a specific religion (Christianity) in a manner which may undermine the commitment to an open-ended spirituality and religious diversity.

Of course it is such predicaments which may lead educators to posit a dichotomy between religion and social work, even when they acknowledge a spiritual dimension to humanity. Quite simply, they are uncomfortable with where the faith-based road might lead, and sometimes with good reason. For example, one educator had experience of students who had been converted to a spiritual path as a result of their training on the 12-steps programme for recovering addicts, and this was deemed to be incompatible with social work interventions which rely upon harm-reduction, substitute substances and cognitive-behavioural therapies (cf. Scott Tonigan et al, 1999):

23 Journal of Practice Teaching \& Learning 8(3) 2008, 7-27. DOI: 10.1921/146066909X478271. @ wEbb 
E: I've had students who believe that the only answer to a drug or alcohol problem is to place yourself in the hands of God. But that's not a social work technique so, you know, there is often conflict there! But it is a basic belief, an act of faith, so it's not something that you can challenge with a piece of scientific evidence. I actually say to them 'Are you sure that you really want to be a social worker?'. I believe that there is a spiritual element to people's well-being, but on the whole social work is a secular business.

Throughout the project there was a pronounced polarisation between interviewees with faith and no faith respectively whereby those who adopted an atheist or agnostic standpoint tended to perceive religion and spirituality as non-relevant or even harmful to social work and society, whilst those from faith backgrounds tended to focus exclusively upon the virtues of religion and spirituality. Transcending such polarisations will hinge upon the capacity of all parties to learn a shared language on faith matters and to dialogue across the inevitable differences of perspective and dialect.

\section{Conclusion}

This exploratory study of the role of religion and spirituality in social work education has illustrated the complexity of dealing with faith matters in a predominantly secular society where faith has become privatised, notwithstanding recent law and policy injunctions to take it into account in service-provision. Those from faith-based traditions may hide their faith in a closet in order to conform to societal and professional norms; the result is that some of their most precious resources for creative practice are concealed from view, along with some stumbling-blocks for anti-oppressive practice. Those with no-faith may also have skeletons in the closet - for example, those who have witnessed wars or abuse in the name of religions have good reasons for repudiating religion - but their lack of faith allows them an opt-out clause as they can dismiss faith matters as irrelevant. In the light of the return of religion and spirituality to social work practice, along with the sustained commitments to faith of minority ethnic communities and some indigenous citizens (which include a significant minority

24 Journal of Practice Teaching \& Learning 8(3) 2008, .7-27. DOI: 10.1921/146066909X478271. @ w\&b 
of students and practitioners), this avoidance of faith needs to be challenged. Indeed, faith is one dimension of the personal-professional interface which has otherwise been granted a special role in facilitating our development as students, practitioners and educators.

I would like to leave readers with a typology of positions in relation to faith and dialogue so that they can consider their own position in relation to those of their students or educators (see Figure 1). There are four basic positions, but in a two-party situation this generates multiple possible combinations of positions. My assumption is that openness to dialogue about faith matters is the ideal to which we should be devoting our efforts in social work education. However, there are at least three scenarios which are problematic. The first is when both parties are willing to dialogue but come from different backgrounds under conditions where one or both of them adopt a dogmatic stance. The second is when there is asymmetry in openness to dialogue, so that one party wants to open up a dialogue when the other has closed the door on this. The third is when both parties are closed off from dialogue; friction is avoided, but if faith matters are relevant then there can be collusion to avoid salient issues. If educators and students are to enter into dialogue on faith matters, then it is vital that they develop what has been dubbed 'spiritual literacy' (King, 2008). This represents a journey into new territories for all of us, whatever our background may be, and it is hoped that this article and its list of references will be helpful on this journey.

Figure 1.

Standpoints on Faith and Dialogue

\begin{tabular}{|c|c|}
\hline $\begin{array}{c}\text { 1. Faith with openness } \\
\text { to dialogue }\end{array}$ & \begin{tabular}{|c|} 
2. Faith closet and \\
closed to dialogue
\end{tabular} \\
\hline \begin{tabular}{|c|} 
3. No-faith with openness \\
to dialogue
\end{tabular} & $\begin{array}{c}\text { 4. No-faith and closed } \\
\text { to dialogue }\end{array}$ \\
\hline
\end{tabular}

25 Journal of Practice Teaching \& Learning 8(3) 2008, 7-27. DOI: 10.1921/146066909X478271. @ wËb 


\section{References}

Berger, P. L. (1969) A Rumour of Angels: Modern society and the rediscovery of the supernatural. London: Penguin

Bywaters, J. and Jones, R. (2007) Sexuality and Social Work. Exeter: Learning Matters

Canda, E. R. and Furman, L. D. (1999) Spiritual Diversity in Social Work Practice: The heart of helping. New York: The Free Press

Clarke, C.L. (2000) Social Work Ethics: Politics, principles and practice. Basingstoke: Palgrave Macmillan

Coghlan, D. and Brannick, T. (2005) Doing Action Research in Your Own Organisation. London: Sage

Coles, R. (1990) The Spiritual Life of Children. Boston: Houghton Mifflin

Consedine, J. (2002) Spirituality and social justice. In M. Nash and B. Stewart (Eds.) Spirituality and Social Care: Contributing to personal and community well-being. London: Jessica Kingsley

Coyte, M. E., Gilbert, P. and Nicholls, V. (Eds.) (2007) Spirituality, Values and Mental Health: Jewels for the journey. London: Jessica Kingsley

Crompton, M. (1998) Children, Spirituality, Religion and Social Work. Aldershot: Ashgate.

Dominelli, L. (1997) Anti-Racist Social Work. Basingstoke: Palgrave Macmillan

Eastham, M. (2002) Vocation and social care. in M. Nash and B. Stewart (Eds.) Spirituality and Social Care: Contributing to personal and community well-being. London: Jessica Kingsley

Furman, L.D., Benson, P.W., Grimwood, C. and Canda, E. (2004) Religion and spirituality in social work education and direct practice at the millennium: A survey of UK social workers. British Journal of Social Work, 34, 6, 767-792

General Social Care Council (2002) Code of Practice for Social Care Workers. London: GSCC

Giddens, A. (1990) The Consequences of Modernity. Oxford: Polity Press

Gilligan, P. (2003) 'It isn't discussed'. Religion, belief and practice teaching: Missing components of cultural competence in social work. Journal of Practice Teaching, 5, 1, 75-95

Hay, D. and Nye, R. (1998) The Spirit of the Child. London: HarperCollins

Holloway, M. (2007) Spiritual need and the core business of social work, British Journal of Social Work, 37, 2, 265-280

Humphrey, J. C. (1999) Organising sexualities, organised inequalities: Lesbians and gay men in public service occupations. Gender, Work and

26 Journal of Practice Teaching \& Learning 8(3) 2008, .7-27. DOI: 10.1921/146066909X478271. @ w\&b 
Organisation, 6, 3, 134-151

Humphrey, C. (2008) Turning the world upside down. in A. Imoutel and B. Spalek (Eds.) Religion, Spirituality and the Social Sciences: Challenging marginalisation. Bristol: Policy Press

Kennison, P. (2008) Child abuse in the religious context. The abuse of trust. in P. Kennison and A. Goodman (Eds.) Children As Victims. Exeter: Learning Matters

King, U. (2008) Spirituality and gender viewed through a global lens. in A. Imoutel and B. Spalek (Eds.) Religion, Spirituality and the Social Sciences: Challenging marginalisation. Bristol: Policy Press

McSherry, W. (2006) Making Sense of Spirituality in Nursing and Health Care Practice. London: Jessica Kingsley

Miller. W.R. (Ed.) (1999) Integrating Spirituality into Treatment. Resources for practitioners. New York: American Psychological Association

Molloy, M. (2008) Experiencing the World's Religions. Tradition, challenge and change. New York: McGraw-Hill

Moss, B. (2005) Religion and Spirituality. Lyme Regis: Russell House

Nash, M. and Stewart, B. (Eds.) (2002) Spirituality and Social Care: Contributing to personal and community well-being. London: Jessica Kingsley

Ng, S.M. and Chan, C.L. W. (2005) Intervention. in R. Adams, L. Dominelli and M. Payne (Eds.) Social Work Futures: crossing boundaries, transforming practice. Basingstoke: Palgrave Macmillan

Panaser, A. (2003) Sikhing social work. in V. E. Cree (ed.) Becoming a Social Worker. London: Routledge

Payne, M. (2005) Modern Social Work Theory. Basingstoke: Palgrave Macmillan

Rees, D. (2001) Death and Bereavement. The psychological, religious and cultural interfaces. London: Whurr

Ridge, D., Williams, I., Anderson, J. and Elford, J. (2008) Like a prayer: The role of spirituality and religion for people living with HIV in the UK. Sociology of Health and Illness, 30, 3, 413-428

Robinson, S. (2008) Spirituality, Ethics and Care. London: Jessica Kingsley Scott Tonigan, J., Toscova, R. T. and Conors, G. J. (1999) Spirituality and the 12-steps programs: a guide for clinicians. in W.R. Miller (Ed.) Integrating Spirituality into Treatment. Resources for practitioners. New York: American Psychological Association

Woodroofe, K. (1961) From Charity to Social Work in England and the United States. London: Routledge and Kegan Paul

27 Journal of Practice Teaching \& Learning 8(3) 2008, 7-27. DOI: 10.1921/146066909X478271. @ w\&bb 